\title{
IAW-Diskussionspapiere
}

IAW-Discussion Paper

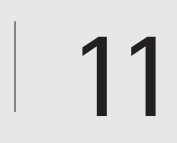

\section{Creating Firms for a New Century: Determinants of Firm Creation around 1900}

Joerg Baten

August 2003

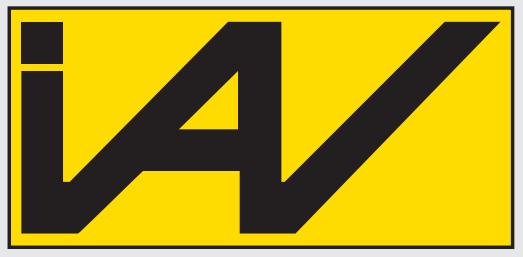

INSTITUT FÜR

Angewandte

WIRTSCHAFTSFORSCHUNG Ob dem Himmelreich 1 72074 Tübingen

T: (0 70 71) 98 96-0

F: (0 70 71) 98 86-99

E-Mail: iaw@iaw.edu Internet: www.iaw.edu

ISSN: 1617-5654 



\section{IAW-Diskussionspapiere}

Das Institut für Angewandte Wirtschaftsforschung (IAW) Tübingen ist ein unabhängiges außeruniversitäres Forschungsinstitut, das am 17. Juli 1957 auf Initiative von Professor Dr. Hans Peter gegründet wurde. Es hat die Aufgabe, Forschungsergebnisse aus dem Gebiet der Wirtschafts- und Sozialwissenschaften auf Fragen der Wirtschaft anzuwenden. Die Tätigkeit des Instituts konzentriert sich auf empirische Wirtschaftsforschung und Politikberatung.

Dieses IAW-Diskussionspapier können Sie auch von unserer IAW-Homepage als pdf-Datei herunterladen:

http://www.iaw.edu/Publikationen/IAW-Diskussionspapiere

\section{ISSN 1617-5654}

Weitere Publikationen des IAW:

- IAW-News (erscheinen 3-4x jährlich)

- IAW-Report (erscheinen 2x jährlich)

- IAW-Wohnungsmonitor Baden-Württemberg (erscheinen 4x jährlich kostenlos)

- IAW-Forschungsberichte

Möchten Sie regelmäßig eine unserer Publikationen erhalten, dann wenden Sie sich bitte an uns:

IAW Tübingen, Ob dem Himmelreich 1, 72074 Tübingen,

Telefon 07071 / 98 96-0

Fax $\quad 07071 / 98$ 96-99

E-Mail: iaw@iaw.edu

Aktuelle Informationen finden Sie auch im Internet unter: http://www.iaw.edu

Der Inhalt der Beiträge in den IAW-Diskussionspapieren liegt in alleiniger Verantwortung der Autoren und stellt nicht notwendigerweise die Meinung des IAW dar. 



\title{
Creating Firms for a New Century: Determinants of Firm Creation around 1900
}

\author{
Joerg Baten
}

\author{
Univ. Tuebingen and CESifo
}

JEL: L20, R12, N63

\author{
Address: \\ Joerg Baten \\ Dept. Economics, Univ. Tuebingen \\ Mohlstr. 36, \\ D-72074 Tuebingen, Germany
}

Email: joerg.baten@.uni-tuebingen.de

I thank for important comments and suggestions on earlier versions by Werner Abelshauser, Albert Carreras, Monika Dickhaus, James Foreman-Peck, Rainer Fremdling, Claude Hillinger, Stefan Klasen, John Komlos, Douglas Puffert, Christian Stoegbauer, Bernd Suessmuth, three anonymous referees, and participants of the German Economic Association (VfS), European Historical Economics, and First German Cliometrics conferences. All remaining errors are mine. Ingeborg David and Axel Heitmueller provided excellent research assistance. I am indebted to the Fritz Thyssen foundation for financial support that enables the collection of large firm data sets on Germany's early $20^{\text {th }}$ and late $19^{\text {th }}$ century economic history.

\begin{abstract}
$\underline{\text { Abstract }}$
A rapidly growing literature in industrial economics and regional economics uses data sets of individual firms or regional firm creation rates to answer the central question: What makes entrepreneurs? Which factors encourage some people to set up their own business and create jobs, and what prevents potential entrepreneurs from doing so? This contribution explores the determinants of regional differences in firm creation rates by using a new data set of 4036 individual firms from Southwest Germany around 1900. Agglomeration effects and earlier firm creations stimulate current firm creation. In addition, a small and medium firm environment allows the formation of specific human capital-another favourable factor for a dynamic firm creation process in some regions.
\end{abstract}





\section{Creating Firms for a New Century: Determinants of Firm Creation around 1900}

As many European countries entered the new millenium with large unemployment rates, the study of firm creation processes is a flourishing field in economics today. In contrast to prior decades in which policy makers believed in the effectiveness of Keynesian economic policy, today's common view is mainly the reverse. Hence decision makers emphasize the role of efficient markets which could lead to higher firm creation rates and thereby to lower unemployment rates. Obviously, if every unemployed person became an entrepreneur, the problem would not exist any longer. Therefore, "entrepreneurship research" is an expanding field which deals with the determinants of firm creation. Aside from direct employment effects, high firm creation rates have a positive impact on the technical and organizational change of economies because new firms are - on average - better equipped with the latest technical and organizational knowledge. The structural change of the economy goes hand in hand with high creation rates which tend to be accompanied with high rates of firm mortality, as some studies argue (Reynolds/Storey/Westhead 1994). New firms can be found in sectors with high profits, whereas firms which are likely to close down in the near future tend to be located in unproductive sectors (Reynolds 1994, p. 430). In addition, some entrants expect to replace less efficient incumbents, see Baldwin (1995).

The causes of regional differences in creation rates are especially subject to intense debates. A series of studies partly coordinated by the OECD looked at those regional determinants (Audretsch/Fritsch 1994, Audretsch/Vivarelli 1994, Davidsson/Lindmark/Olofsson 1994, Reynolds/Storey/Westhead 1994, Gerlach/Wagner 1994, to name but a few). In their crosssectional analyses, Reynolds et al. (1994) and Fritsch (1994) emphasize the importance of the so-called "seed bed" theory. This "seed-bed" consists of small and medium-sized firms in which potential entrepreneurs can achieve a specific human capital: the close contact with the entrepreneur provides opportunities to learn the important skills to run a firm. The weaknesses of some incumbent (i.e. already existing) firm's leaders further encourage to set up one's own firm. Among other causes of regionally higher firm creation rates, agglomeration effects features prominently: a higher concentration of industrial activity in one region leads to positive externalities in the human capital formation process, to "thick" labor and intermediary markets in which entrepreneurs can hire exactly the inputs they need. Apart from those factors, we will also consider in the following variables that are related to cultural factors and mentality. Max Weber has put forward the famous hypothesis that certain features of protestantism are more condusive to entrepreneurial activity and modern economic growth. Although Weber's own theory is more complicated, some of his followers formulated a simplified version saying that protestant regions and countries (such as the UK, USA, Netherlands, Switzerland) develop modern economic growth earlier than others. We will test this simplified Weber thesis below. Still another influence on firm creation has been pointed out by Gerlach and Wagner (1994): the intertemporal persistence of regional differences. Previous firm creation might either stimulate current firm creation because of expected profits being similar in both time periods, or because of a "bounded rationality" type of perception that suggests to potential entrepreneurs that this might be the case. 
Occasionally, a period of enormous firm creation rates is mentioned in the literature - e.g. the phase of rapid industrialization in Germany at the end of the 19th and the beginning of the $20^{\text {th }}$ century. The time period around 1900 might have had a critical mass of firm creators, thus it was possible to achieve substantial economic growth. One of the most important questions in economic history is how such a critical mass developed from Germany's agricultural and craftsmen society of the $19^{\text {th }}$ century. This question is very relevant, because its clarification can help to understand today's issues and solve a part of the unemployment problem.

Economic evidence from this time period has several important advantages for empirical studies of industrial economics. Firm creation studies on the 1980s and 1990s often have to rely on data from questionnaires that typically underly return selectivity. The relative importance of the different determinants of non-response is normally unclear. In contrast, our historical samples contain almost all of the firms (given the definitions below). Secondly, the variety of regional economic policy today makes it difficult to identify econometrically which part of entrepreneurial behaviour is caused by these measures, and which part is caused by other factors. ${ }^{1}$ On the other hand, opponents could argue that human behaviour of the $1980 \mathrm{~s}$ and 1990s might have greater similarities to the human behaviour of the early $21^{\text {st }}$ century (that we want to understand and predict) than human behaviour around 1900. But recent studies have shown that important aspects of the economic situation were actually more similar around 1900 and around 2000: For example, international capital market integration was at a similarly high level in those two periods, than it was in the meantime of the 1920 s to early 1980s (O’Rourke and Williamson 1999; Taylor 1996).

Almost in every country, there are dynamic regions with high rates of firm creation, on the one hand, and less dynamic ones, on the other. In today's Italy, for example, the EmiliaRomagna developed a reputation for its many new small firms in the fashion industry. California's Silicon Valley is probably the best-known example of a region with a flourishing high tech small firm sector and high creation rates. Regional research on firm creation focuses on the characteristics that distinguish these dynamic regions from other ones that are displaying less dynamism. Baden in 1900 was an area of economic growth, being in a way representative for developing Germany: it had some regions that were dynamic with many firm creations, whereas others were lagging behind. What exactly was Baden's economic position within Germany? Was it a prosperous region, or a backwater of Germany? If the latter were the case, one could imagine that many of the firm creations analysed later-on were born out of sheer misery. Tax-based regional estimates of GDP per capita in 1913 suggest that Baden takes a middle position within Germany: the Bezirke (Baden had 4 Bezirke) Mannheim and Karlsruhe were 10\% and 13\% above the German average, Freiburg and Konstanz were 13\% and 18\% below average (Frank 1994; Handbuch 1992). Interestingly, rural and urban unskilled (nominal) wages were relatively high in Baden (Table 1): The rural wages of the four main regional units ranged from the $69^{\text {th }}$ to the 81 th percentiles of German wages, the urban wages were even relatively higher (the data refer to 1897, Central-Blatt, Anhang zu Nr. 52 1897). Of course, nominal wages do not tell us much about living

1 In addition, historical evidence has the great advantage that business secrets do not play a large role -but this feature is not used in the present study. For example, tax declarations are not secret after 80 years, and firm archives keep records of secret decisions that today's CEOs would not make accessible. 
standards, but regional cost-of-living estimates are difficult to obtain. We formed a very rough regional consumer price index from rye flour and pork in the major German regions, and found that prices in Baden were relatively high. The real wages in Baden ranged from the $47^{\text {th }}$ to the $65^{\text {th }}$ percentile. The high prices and wages might have been stimulated by high population density and the demand for goods and labor in Switzerland and Upper Alsace, two adjacent regions of Baden. Interestingly, human capital formation in Baden was already around 1900 far above the German average (see also Fischer 1989). ${ }^{2}$ Three of the four major regions were far above the median, Mannheim even reached the $83^{\text {rd }}$ percentile of German patenting activity. This level of inventive activity was certainly promising for the future. Parts of those regions might be compared with Silicon valley (especially the cities of Mannheim and Karlsruhe, see Borscheid 1976, Abelshauser 2002).

Recent research on firm creation has developed the strategy of counting the number of created firms in a region and relating it to the regional population (or to the workforce), i.e. confronting the creators with the non-creators. This creation rate (abbreviated CR) will be our dependent variable. A helpful finding in this context was the fact that the overwhelming majority of firm founders set up their business at their place of residence, as Fritsch (1994) demonstrated. ${ }^{3}$ We will employ these methods for evaluating the firm creation record of the late $19^{\text {th }}$ and early $20^{\text {th }}$ century in the South German state of Baden that had excellent statistics and other advantages described below.

\section{Sources for firm creation rates around 1900}

Restricting the analysis to Baden is necessary because none of the other German states kept records of all newly created firms by year of creation on a low level of regional aggregation. But Baden has important additional advantages, making it an ideal test case: Most of its industries were "footloose" industries: As almost no important natural resources were available (except the wood that gave rise to a small number of lumber firms), nearly all firms that were created in Baden could theoretically have been created elsewhere, or anywhere within this state. Another advantage of Baden is the concentration of human capital intensive industries. This land is typical for the machine building and chemical industries that led to Germany's long-run success (for more details, see Baten 2001, p. 86). Therefore, it is particularly interesting to study this region on the background of today's human capital intensive development. Finally, Baden is a good land to study because it has no clear coreperiphery structure, but many medium-sized cities. If France or the region around Berlin would have been studied instead, we would have to deal with this core-periphery structure in a special way.

As we want to connect the firm creation process with regional characteristics, we have to choose a reasonable level of aggregation. An astonishing lot of information was published on the 52 districts (Amtsbezirke), so this level of aggregation is attractive. However, the

2 We measure this as the number of patents that were prolonged for ten years of more, in order to meet the criticism against patents that often disappear soon.

3 This research strategy has considerable advantages compared with methods dealing with groups of entrepreneurs only, because the large majority of people not setting up businesses is taken into account. 
question arises whether these geographical units are not too large or too small. If the level of aggregation would be too small, the place where potential creators are living and where they create firms could be artificially separated. Too large regions on the other hand lead to small numbers of cases and a possible averaging out of regional differences (for example, agglomeration effects). A generally accepted criterion is the size of labor market areas (Reynolds 1994). But we do not have enough information to determine the size of labor market areas by cluster analysis or similar techniques. Instead, we will employ two levels of regional aggregation in the following: In addition to the district level, we will also consider cities as regional units. Other important features of firm creation data sets are the criteria they apply with respect to minimum firm size and minimum survival time (Reynolds 1994, Solar 1997). Many studies strive to restrict their data sets according to some criterion of influence: Fritsch (1994) selected only firms that survived more than a year and had more than just one employee. This has the advantage that firms with almost no impact on the regional economy are disregarded. Our first data source are the establishment lists created by the factory inspectors that record all establishments with 10 and more workers, 4036 in total, for 1895 and 1906. Firm creation rates are then calculated as the number of created firms per 10000 labor market participants. Our second data source is the number of all newly registered firm creations in one year - we used the year 1896, because most of our explanatory variables refer to 1895 , so that choosing 1896 for the dependent variable avoids the problem of contemporaneous correlation. This source, recorded on a district level, also includes firms with 0-9 workers.

A methodological problem arises from the fact that the creation of branches ["works" that are not independent] does not reflect local or regional characteristics of the creator, because those creations often take place far away from the entrepreneur's place of residence. Fortunately, we have been able to identify most of the branch creations in our data set. ${ }^{4}$ However, for the first part of our analyses we adjust our mode of measurement to the studies reported above, including both "companies" and "works" to be able to draw comparisons with the previous literature. In contrast to our historical data sets, those studies on the 1980s were faced with enormous problems identifying branches, because this information was unavailable due to the legal restriction of data protection (Datenschutz). For example, Fritsch (1994) had to include all branches among his firms. He only excluded those firms with an initial size of 50 and more workers, because he assumed that those were branches, since "newly created, independent firms typically start small". We will definitely exclude branches ("works" that were not independent) in the last part of the paper. We have to admit though that the results change only modestly if branches are excluded (branches represent about $12.5 \%$ of the total stock of firms).

Apart from the branch question, we will also adjust the specification of our regression to the cited literature. For example, a logarithmic transformation will not be used in the first set of regressions.

$4 \quad$ Very small branches that were situated in the same street as the central establishment, were not entered as separate data sets. Their number of workers was added to the main establishment. 


\section{Hypotheses}

We begin with an income choice model in which the probability to create a firm in time period $t$ is dependent on the expected entrepreneurial income, and its opportunity costs, the otherwise expected wage. We use the stylized fact that the largest share of new entrepreneurs created firms in the place of their previous residence. This observation serves as a justification to calculate their opportunity cost as being the wage they would have earned otherwise, and not the foregone profit from not creating a firm elsewhere. This is a well-founded empirical fact (Fritsch 1994, Audretsch/Vivarelli 1994), but still it is astonishing. Why is the opportunity cost of creating a firm in region i not simply the cost of creating a firm in another region? It seems as if personal networks help to reduce the costs (including psychological costs) of creating a firm dramatically. It is also remarkable that some firm creators went to foreign countries, before setting up a firm in the village next to which they were born. For example, Franz Xaver Heine who was born in Voehrenbach in the Southern Blackwood went to Russia for several years and visited France, Switzerland and England, before creating a clock-producing firm in his small village of birth - and there were more cases of this kind (Bender 1978).

Interestingly, the creation of a new branch of a firm is much more frequently done in an alternative region: once firm creators did experience their ability to run an independent firm successfully in their own place, they start to export this entrepreneurial activity into other regions. ${ }^{6}$ But the original act of firm creation is most often done at the earlier place of residence, as previous questionaire and interview studies demonstrated. We also have to keep in mind that the potential number of firm creators is enormously large in any region: there are typically 2-4 firm creations per 10000 labor force annually, and less than one creation reaches the level of 10 workers after 5-10 years. Therefore, what we are modelling (and later observing in most cases) is the decision of a previously salaried worker to switch from wage labor to firm creation in his own community or district. ${ }^{7}$

5 The literature on firm creations by industry in contrast does not use firm creations per labor force (Audretsch and Fritsch 1994 called this the "labor market approach"), but calculates the creation rate as the number of new firms per 100 existing firms, see Orr (1974) and Geroski (1991).

6 Those other regions are selected according to favorable input costs (such as low wages). In a separate analysis, we regressed the creation of branches on a variety of explanatory variables and found that low wages are an important predictor for firm creations (regressions not shown here).

7 Those people also typically do not run a firm part-time, parallel to continuing working in a wage labor position. 
We aggregate the choice to create a firm over $n$ inhabitants of a given region:

$$
\mathrm{CR}_{\mathrm{t}}=1 / \mathrm{n} \sum_{i=1}^{n} f\left(\Pi_{i}^{*}-W_{i}^{*}\right)
$$

where

$\mathrm{CR}_{\mathrm{t}} \quad$ firm creation rate in year $\mathrm{t}$ in a given region

$\Pi_{\mathrm{i}}^{*} \quad$ expected profit of individual i (net, minus costs for coping with barriers plus

$\mathrm{W}_{\mathrm{i}}^{*} \quad$ expected wage of individual $\mathrm{i}$

The expected entrepreneurial income as well as the expected wage depends on a vector of factors:

SYMBOL

$\Pi_{\mathrm{i}}^{*}=\mathrm{f}\left(\mathrm{AGGLO}=\mathrm{HUMCAP}, \mathrm{SME} \_\mathrm{SEED}, \mathrm{HISTORY}, \mathrm{FCOST}, \mathrm{OTHER}, \varepsilon\right)$

$\mathrm{W}_{\mathrm{i}}^{*}=\mathrm{f}(\mathrm{WAGE}, \mathrm{UNEMP}, \varepsilon)$

where

SYMBOL

AGGLO

HUMCAP: agglomeration externalities and human capital stock

SME_SEED: "seed-bed effect": entrepreneurial human capital formation and network externalities of small \& medium enterprises

HISTORY the creation rate of the previous period might either proxy profit expectations (because of costs and benefits not controlled with other variables), or learning and imitation effects

FCOST the two main factor costs: costs of capital and labor

OTHER other promoting or preventing factors are policy issues (such as taxation and infrastructure investments, touristic specialisation (to be explained below), and mentality-related variables

WAGE current wage level

UNEMP unemployment rate (not very important for the period under study).

We will comment on those factors and their proxies in greater detail below. 


\section{Hypothesis 1: Agglomeration and human capital effects}

Based partly on Marshall's finding that agglomeration effects result from external increasing returns in production and especially the development of thicker input or factor markets, notably for labor, Krugman (1991) suggested a model to explain the uneven economic growth of regions. Firm creation does not directly appear in his model, but he focuses on the growth of industrial labor force agglomerations. This growth of the labor force takes place partly by the growth of existing firms and partly by creation of new firms.

Krugman does not model entrepreneurial incomes, land rents etc, his main element of model closure is the adjustment of real and nominal wages in different regions: Increasing returns to scale at the firm level lead to cheaper products and increase the regional real wages. Those attract workers from low wage regions, in turn increasing the share of the total industrial labor force living in this agglomerated region, and a still higher number of products will be produced there. Opposed to this force promoting agglomeration stand centrifugal transportation cost (that work against agglomerations: the higher those are, the less agglomerated is the resulting equilibrium) and nominal wage increases (from the firms' perspective).

In our study, we will employ the share of the industrial and service (i.e., nonfarm) sector labor force in the region as a proxy for agglomeration effects, to keep it close to Krugman's model. This variable captures the strong migration movements to the emerging centres of industry. The previous literature has used a variety of indicators to measure agglomeration effects. Apart from obvious variables such as population density, the share of people aged 2544 is often considered (Table 2, which is adapted from Reynolds/Storey/Westhead 1994, p. 451). It has been argued that where the members of these age group migrate, a strong urbanity should probably exist (even if population density is not necessarily highest, as in the Los Angeles region, for example, see Reynolds et al., 1994). Agglomeration and human capital tend to be highly correlated and the independent effect of each component is difficult to isolate in regression analyses. Surprisingly, both variables have been insignificant in many country studies. Only the share of managers has been significant in the Anglo-Saxon cases. For Ireland and the USA the coefficient on population density turns out to be negative, maybe because industrial firms choose their location outside of the cities (even if they remain often close to the metropolises. Results of agglomeration effects therefore depend on the level of geographic aggregation). For Germany, Italy, and the UK the coefficients have been significantly positive.

\section{Hypothesis 2: "Seed-bed" effect: SME environment and regional specialization}

Are firm creations promoted more by large firms (supplier relations) or small firm environments ("seed-beds"). A large firm in one region might mean good possibilities for potential entrepreneurs to set up new firms supplying parts and auxiliary services. For example, the firm creation activity in the Munich area has been attributed to the move of the Siemens company from Berlin to Munich after World War II. On the other hand, a high percentage of the labor force working in small firms has been hypothesized to have a positive influence on the propensity to create firms. The reasoning behind this latter hypothesis, also called "seed bed theory", is the empirically observed fact that many firm creators work in small firms 
before setting up their own business. Because small firms employ a less specialized management, their managers are responsible for a broad range of activities and therefore achieve a wide range of entrepreneurial human capital. In contrast, managers in large firms tend to be highly specialized, lacking the broad knowledge how to run a whole firm. Other factors that motivate managers and technically skilled persons from small firms to set up their own business is the lower salary in small firms and the higher probability of firm failure. (On the wage differential by firm size, see Gerlach/Schmidt, 1990. On high failure rates of small firms, see Storey et al., 1987). The same managers in large firms would have better career possibilities and would less often take an own business into consideration. So we have opposing views here, making it fascinating to test the two hypotheses empirically: Do Siemens and other large firms stimulate firm creation, or does a high share of SME employees lead to high creation activity?

This seed-bed factor is measured as the share of employees in small and medium sized enterprises (in the following also called "SME factor"). In studies on the 1980s firm creation rates, this variable showed a positively significant relationship with the creation rates in six countries (Table 2). Hence the variable SME plays a crucial role in the forthcoming analysis.

Fritsch (1994) supported this view by showing that the share of skilled workers in small firms has an even more systematic impact. (Fritsch 1994, Table 4, p. 32/33). ${ }^{8}$ Some papers focus on the role of regional spezialization. In "industrial districts" new and small firms are easily able to assess the market and their potential profit opportunities (Sabel/Zeitlin, 1997). Transaction costs are supposed to be lower and knowledge is transferred more efficiently. Ex ante the probability of failure declines. The staff in those enterprises are more likely to gain an overview of potential market niches and to set up their own firms.

\section{Hypothesis 3: History: "Learning by example" and other autocorrelated effects}

Firm creations in the previous period might have taken place, because the profit opportunities were favorable - apart from the factor costs and and other promoting or preventing variables that we control for. Another mechanism how past creations can influence current firm formation rates is imitative behaviour (reflecting perhaps bounded rationality behaviour). Thirdly, technological achievements of individual entrepreneurs could create knowledge externalities for following entrepreneurs. This can be conceptualized as a learning curve with limited knowledge transfer possibilities. The duration of firm activity is plotted on the $\mathrm{x}$ axis against downward sloping short-run average cost on the y-axis. If no externalities existed, each firm would have to start at the highest point of this learning curve, and with experience gradually move down to lower average cost levels. However, if knowledge transfers are possible, new firms can start at a point further to the right, at a lower average cost level. ${ }^{9}$

8 However, Audretsch and Fritsch (1995) differentiated between manufacturing and services industries and they found that the predominance of small firms had no effect on the rate of manufacturing start-ups, presumably because scale economies were much more relevant in manufacturing. Thanks to an anonymous referee for this hint.

9 This might also play a role for the literature on path dependence, see, for example, Puffert (2002). 
Technology is broadly defined here including all other knowledge components the lack of which might keep somebody from creating a firm in spite of higher expected income: How to live with higher risks, how to deal with employees, with criminality, the need to declare taxes, and similar issues. We test this argument in the following by taking into account the firm creation rates of the past. In other words, the previous firm creation serves as a proxy for the "learning by example" effects, because potential entrepreneurs can learn much a firm creation in the previous period.

\section{Hypothesis 4: Main factor costs: Capital and wage costs}

One of the first problems potential entrepreneurs are faced with is the access to capital. A frequent reason for firm mortality is illiquidity during the first years of the firm's life cycle.

Very few firm creators receive their whole initial capital stock from banks, and if they do, the interest rates are extremely high (in the absence of exogenous wealth). Typically, a large share of initial capital stems from their own savings, or it is borrowed from relatives and friends. Houses and land often serve as securities for the remaining sum. Therefore many contributions in this field directly employ the price of houses in a region or the share of owner-occupied apartments as indicator for capital availability. However, most of these indicators remain insignificant in the six studies (Table 2); only the price of houses is significantly positive in the U.S. (although it might as well proxy other factors).

As a proxy for the local access to capital we employ the (money) capital tax per population. This tax was levied on capital that is not invested in the owner's firm. This variable is a good proxy for the local availability of capita.

Labor costs are the second main item in the entrepreneurial calculation. Low wages might encourage potential entrepreneurs, both because of modest explicit labor costs and low opportunity costs. However, wages are sometimes proxies for human capital aspects that are difficult to measure with schooling and similar variables. This fact leaves us with a slightly ambiguous expectation about the impact of wages on creation propensity. We proxy this variable with the unskilled day-labourer's wage.

\section{Other Hypotheses}

Some additional factors are considered by research on creation activity in the 1980s, but those turned out to be of minor importance or ambiguous impact in previous empirical studies (regional economic policy, unemployment), or they might be endogenous from a microeconomic point of view (demand growth). In our study, we will consider additional factors such as regional taxation (Hallerberg 1995), railway infrastructure, and tourist orientation: Regional taxation is an obvious cost factor for firm creations. We measure it with a dummy variable that is one if the taxation by the local communities is higher than average. Railway infrastructure reduces costs for intermediaries, energy, and for the distribution of final 
products. We measure it as being one if a district lies on a main railway line. Tourist orientation is an interesting variable, because one would expect that tourist regions provided ample opportunities for creating a flood of firms: hotels, restaurants, small pensions, and all kinds of services from taxis to massage. ${ }^{10}$ On the other hand, tourism is an industry that exists symbiotically with agriculture, and suffers easily from negative externalities of industrial production: Who would love to sleep in a hotel close to a chemical plant? Who would want to step out of a casino (such as the one in Baden-Baden) and hear the machinery noise of a steel processing firm? In regions that specialized in the tourism industry around 1900, we could also expect lower rates of firm creation in the industrial sector. Cities like Freiburg or Heidelberg which lived from tourism and the immigration of rich retired people would not tolerate noisy establishments of the metal processing industry. Also in the region of Muellheim, many people earned their living from tourists who were attracted by the mineral springs. We measure this factor with the employment share in tourism. ${ }^{11}$

\section{$\underline{\text { Results at the "district" level of aggregation }}$}

Before considering causal models, we will first take a closer look at the dependent variable: the geographical differences of firm creation rates in Baden around 1900 are shown in map 1. Dark areas represent higher creation rates. A strong activity was concentrated in the larger cities of Mannheim, Heidelberg, Freiburg and Pforzheim, even though other big cities such as Karlsruhe and Konstanz had only moderate rates. Less urbanized regions with a strong creation activity were Wiesloch, Bruchsal/Eppingen, and Lahr/Ettenheim, where particularly many tobacco processing firms settled (Boelcke 1987). Triberg and Villingen, centres of German clock manufacturing, were also above average. Clearly less activity was visible in the Northeast (except Buchen/Wertheim), and the Southeast (except Messkirch). Some parts of the Southwest (Muellheim, Staufen) and the central part (Baden, Rastatt) have surprisingly low rates: one would expect the good transport facilities of those regions to have created a more dynamic regional economy. Because we find below that urban agglomeration implies higher creation rates, the residuals were calculated from a regression of firm creation rates on

10 I thank an anonymous referee for raising this point.

11 The negative influence of tourism on firm creation that we will find below was not caused by underreporting of newly created firms in the tourism sector (we define this sector as: "hotels, restaurants, and other recreative business". We cannot separate out restaurants that mainly addressed local people). In some districts, the number of firm creations in tourism was actually high - especially in Freiburg (205 new firms in this sector 1896 of 432 in total) and Heidelberg, in other cities is was low: Mannheim had 9 new "recreative firms" among 645 total newly created firms (those numbers do not apply a minimum survival criterion). The effect is driven by the low overall creation rates in most of the tourist-oriented districts (Baden-Baden, Muellheim, Black Forest districts). 
the agglomeration indicator. ${ }^{13}$ Those residuals - which can be thought of as the firm creation rates after the agglomeration factor has been controlled for - are shown in map 2. A whole area of lower creation propensity than expected from the agglomeration factor becomes visible in the Southwest, around Schopfheim and Schoenau. This is a traditional textile region, with relatively large firms. This would support the notion of a low share of SME tending to suppress creation activity. Other lower-than-expected rates remain in Baden-Baden and Karlsruhe, whereas the Northeast and Southeast is closer to the average now.

One potential problem of regional analysis could be spatial autocorrelation: if adjacent regions are either infected by high creation rates of their neighbours (positive spatial autocorrelation), or if they are negatively affected, spatial autocorrelation might make the estimates inefficient. ${ }^{14}$ However, the maps do indicate neither positive nor negative autocorrelation. There are several regions of high and low creation activities spread over the country, and only a limited number of adjacent regions that have both high (or low) values (if there would be no clusters at all, we would have negative autocorrelation). ${ }^{15}$

We therefore proceed to analyze the determinants of regional creation rates in a straightforward regression model (before checking some other possible problems). To make results comparable to those of the OECD studies cited in Table 2. We use BETA coefficients instead of non-standardized coefficients. The proportion of SME (employees in small and medium sized enterprises) turns out to be significant also in the historical time period (Table 3, col. 2). One might conclude that this aspect of the generation process of entrepreneurs around 1900 was similar to the one that Fritsch (1994) and Audretsch/Fritsch (1994) predicted for the western part of Germany today (and the OECD-coordinated studies for other countries). However, there were also differences. The share of population working in industry and services regions (or proxy for industrial agglomeration) shows the expected positive impact on the creation rate of firms in Baden around 1900, but not for the 1980s. The access to capital was clearly positive for this historical sample, including all samples (column 2), and highly significant. Finally, a regional specialization towards tourism has a robust, negative effect on firm creation in the industrial sector. The BETA coefficients indicate that the SME and agglomeration factors were of slightly smaller importance compared with the tourism and capital access factor.

We will analyze the robustness of our findings by using our second source, the creation rates based on data of newly opened firms in 1897-1905. In contrast to the estimations above which included all firms, we now include those that expanded to 10 and more employees in 1906 (Table 3, Column 3 to 5). This has the advantage that we can measure firm creations that had a certain degree of success and employment impact in the medium run. In general, the same coefficients are significant (except capital access) with the expected signs (Column

13 The percentage of non-agricultural occupations.

14 For example, the unlikely case that all entrepreneurs are drawn into one regional centre would lead to negative spatial autocorrelation.

15 We did not perform formal tests for autocorrelation, because experts warned us that the long-stretched geographical nature of Baden might provide inconclusive results. 
3). ${ }^{16}$ The local feasibility of capital (proxied with available money capital that was subject to the money capital tax, per capita) shows a positive impact on the creation rates of all industrial firms, including the very small ones (Column 2). However, concentrating on large firms (Column 3-4), the feasibility of capital turns out to be insignificant (just as in Fritsch 1994). It is likely that this difference between small and large firms can be explained by their different mode of finance: While small firms depended on capital from families and friends, larger and rapidly growing firms might have had better access to nationwide sources of financing. In the regression of those firms' creation rates the BETA coefficient of industrial agglomeration is larger than the other BETAs, it might be slightly more important for this group of entries.

We experimented with two human capital proxies, the number of patents per capita and the number of students at industrial schools per capita (not shown in the table, see Baten 2001, pp. 137). We found that both the agglomeration variable and the human capital proxies had independent (positive) effects. The elasticities of patents was $0.26-0.38$, and the ones of students of technical schools was 0.18-0.28. The effect of industrial agglomeration on firm creation declined by about $30 \%$, if the human capital variables were included, but remained significant and larger than the human capital effect. We therefore conclude that there was both an agglomeration and an human capital effect that influences the firm creation rate positively.

Column 4 includes a dummy variable for districts that were connected to the main railway lines. The insignificant coefficient suggests that it did not have a decisive impact, after controlling for agglomeration. The coefficients for agglomeration (industry and services population), SME structure, and tourism are robust to these changes in specification.

While taxation by the state was homogenous in Baden, the cities and villages also had the right to tax their inhabitants, and those taxes were not negligible compared with state taxes (Voigtel 1903). We therefore include a dummy variable in column 5 that is 1 for those districts in which the majority of communes levied more than a 1 percent tax on industrial income. However, this coefficient is insignificant and remains so in other specifications. This might be explained by the fact that taxes in general were considerably lower than they are today, so that tax exemption on a local level might have played only a minor role compared with the other locational determinants. We also assessed the potential influence of wages and firm mortality and found it insignificant (Table 3, Column 4 and 5). ${ }^{17}$

16 It does not matter whether we proxy the agglomeration effect by the employment share in industry and services or by population density. These variables are highly correlated (correlation coefficient of $0.74, \mathrm{p}=0.00$ ), and including either of these variables to the model leads to similar outcomes.

17 We assumed that natural firm mortality, for example caused by the death of an entrepreneur, is similar across regions. We are interested in differences of firm mortality that might be caused by regional characteristics and developments. Both positive and negative influences on firm creation could be hypothesized: if a high share of firms goes bankrupt, potential firm creators can be discouraged. On the other hand, a high firm mortality could open many possibilities for new firms to enter the market. 
When testing causal models with cross-sectional data, one natural question is whether we were able to include all important variables, or whether there might be omitted variable bias arising often from unobserved regional heterogeneity. In those cases, a common strategy is to use panel data and fixed effects estimation that is more robust against unobserved heterogeneity. In the previous literature on firm creation, so far only Gerlach and Wagner (1994) have approached this problem by comparing the simple regression specification with alternative estimates obtained by including regional fixed-effects dummies. Under this specification, the SME factor lost its statistical significance in their sample of Lower Saxonian firms of the 1980s (whereas the fixed effect dummies were significant). However, the size of the coefficients did not decline very much (and remained economically meaningful). This effect often appears if a large number of new variables are entered into the regression model, because the amount of variance in the dependent variable has to be "shared" by more explanatory variables. We interpret this result as an indication that there was actually an independent effect both of SME and of regional fixed effects in the Lower Saxonian sample. In our case, we are not able to construct a panel data set to estimate a model with regional fixed effects, but the next best thing to do is to add a set of regional variables that might capture some unobserved heterogeneity for slightly larger regions. We use the separation of Baden into 11 Kreise. ${ }^{18}$ We find that the three core variables remain significant, even if we control for unobserved regional heterogeneity (column 5 in Table 3 ). We have deviated here from the OECD specification and instead used natural logarithms of all variables so that we can interpret the coefficients as elasticities. ${ }^{19}$ It turns out that al the core elasticities are also economically meaningful: A $1 \%$ higher share of SME employment leads to a $0.9 \%$ increase in firm creation. The same marginal change in agglomeration almost doubles new firm entry.

\section{Did Weber's "Protestant entrepreneur" prevail in Baden?}

Many contemporaries of our firm creators and among the following generations were fascinated by Max Weber's theory of the religious influence on entrepreneurship. Weber (1924) hypothesized that religion had an exogenous influence that led Protestants and especially Calvinists to play an important role in the fundamental economic upswing since the 16th century. He based his argument on the leading role of English, Scottish, Swiss, Dutch and U.S. Protestants during the industrial and 'industrious' revolutions (de Vries 1994). Even in predominantly Catholic countries and regions, the Protestants had a higher probability of being entrepreneurs, for example in France, Germany (especially in the Rhineland), and Hungary. Weber hypothesized that the human capital formation that stemmed from the Protestant insistence in (bible) reading ability played a role. Another factor was the higher propensity to save, because consumption was almost equaled to sin and Protestants could not remove sins by confession. Finally the Calvinists developed the idea that God indicated already on earth those persons who led a holy life by allowing them relatively high wealth. This led Calvinists in Weber's view to a life of permanent work, trying to create a self-fulfilling prophecy. His international comparisons have been criticised because of the small

18 Instead of a fixed effects estimation based on the 52 districts that would not be possible with a pure cross-section

19 Changing the specification has the advantage that we can assess the robustness of the model against those changes. However, columns 2-4 would not change much under this different specification. 
number of cases and the existence of counter-examples such as Northern Italy and Belgium, where Catholic societies developed a capitalistic spirit. Weber defended his position by refering to contemporary studies on Bavaria, Baden, and Hungary that reported a higher propensity of Protestant students in those confessionally mixed countries to visit technical and business colleges, while their Catholic colleagues preferred humanistic colleges that put greater emphasis on religion and ancient languages. According to studies of this type, Catholic craftsmen also tended to remain in their traditional fields, while a higher proportion of Protestant craftsmen moved into the factories and formed a worker aristocracy there. I would follow Weber's critics in that he did not separate carefully enough the effects of religion and minority status, which, given a certain level of human capital, tends to increase the propensity to set up businesses - partly because dependent employment is more often restricted.

Baden offers an opportunity to test this hypothesis, as the share of Protestants differed considerably among regions. We reformulate Weber's argument into a simplified version of his hypothesis: Did a higher share of Protestants lead to a higher firm creation rate? We notice indeed a significantly positive coefficient of this variable (Table 4, Column 1). However, if we control for the other variables that we found to influence firm creation rates, the significance of Protestantism disappears (Table 4, col. 3). This insignificance is not caused by strong multicollinearity, none of the other regressors is highly correlated (all correlation coefficients less than 0.5 ). The modest collinearity is sufficient to let the Protestant variable become insignificant. Hence, we reject this simplified version of Weber's hypothesis for the case of Baden.

Another religious minority in Baden was the Jews. Weber downplayed the impact of this minority - in contrast to Sombart - although his opinion was based only on his theorizing about the economic effect of religious beliefs, not on empirical research (Bischoff 1944). The popular opinion in late 19th and early 20th century that the trading sector contributed little to overall economic growth might have added to this negative judgement, as the Jews were particularly specialized in this field (a result of medieval laws that constrained their economic activities). In our regression analysis, the percentage of Jewish population has a significant positive effect on the firm creation rate in industry (Table 4, Column 2). However, in contrast to the Protestant variable, this influence remains weakly significant after controlling for the other factors such as agglomeration, tourism etc. (Table 3, Column 3). The BETA coefficient is somewhat lower though. This finding also contradicts both Weber's argument and it disproves anti-semitic beliefs of the late $19^{\text {th }}$ and early $20^{\text {th }}$ centuries. In contrast, our finding indicates a positive (although weak) influence of a Jewish minority on the firm creation process, whereas Protestant presence does not explain regional differences.

\section{Potential endogeneity of the explanatory variables}

Agglomeration can result in higher firm creation rates, but Krugman's model also predicts that an expansion in the number of firms attracts additional workers, leading in turn to increasing agglomeration. Reverse causation or bi-directional "repercussion" effect can both be imagined. Another variable that we assumed to be exogenous in previous regressions is the SME enviroment. The exogeneity of this variable, however, has also not yet been 
systematically analyzed, neither theoretically nor empirically. Theoretically, several interpretations of an endogenous SME factor can be thought of. A high rate of creation of a given region in the past can lead to a high percentage of small and medium sized firms, because those newly created firms have not fully grown yet. In other, less dynamic regions, older firms will have had a longer time span to grow, causing their share of employment to be large. One possibility to test which direction of causality is more important would be to perform Granger causality tests, but suitable annual data are not available (in addition, Granger "causality" is mainly a measure for precedence).

We will use two stage least square (abbreviated 2SLS from now) estimation techniques to test for endogeneity of the agglomeration and SME variables, and to arrive at unbiased estimates if the endogeneity hypothesis should be confirmed. In order to run a 2SLS regression, instrumental variables are required that need to be correlated with the potentially endogenous variables, but not with the ultimate dependent variable (the creation rate in our case). They should also not be causally linked with the dependent variable, except through the potentially endogenous variable. Now, what could be proxies (instruments) of the SME environment that are not correlated with firm creation? One characteristic of small firms in Baden around 1900 was that they used much less steam power than large firms. We therefore use the inverse of the number of steam engines per employment as an instrument for the SME environment. By similar considerations, we use the fertility rate as an instrument for agglomeration. ${ }^{20}$ Both instruments are significantly correlated in the order or 0.40 to 0.50 with their respective potentially endogenous variables, but they are not significantly correlated with regional creation rates. As a result of the 2 SLS estimation, agglomeration and tourist orientation remain significant, the agglomeration coefficient even gains in size (Table 5. Column 1). The SME variable becomes statistically insignificant, but its coefficient remains economically meaningful with an elasticity of 0.85: Even if the influence of this variable might be less systematic (there is more variation around the regression line) than we thought before, its economic importance is still visible.

Are those results significantly different from an OLS regression? ${ }^{21}$ The Hausman test is a tool to compare whether the two estimation techniques result in such a difference. In exactly the same specification as we did our 2SLS, we performed an OLS estimate, compared the differences of the individual coefficients and the constant, and calculated the Hausman test. In this case, the p-value of the Hausman test is 0.89 . Thus the null hypothesis that differences in coefficients are not systematic cannot be rejected, and the OLS estimation with its fully efficient estimates is actually preferred.

20 Thanks to Stefan Klasen for suggesting this instrument at the German Clio conference.

21 One could, in principle, construct firm creation rates, SME, and agglomeration variables for three points in time. However, the variation over time would not be useful and sufficient for a fixed effects analysis due to large measurement error. The exercise is only helpful to increase the number of observations. We actually experimented with this panel data set with 3 periods and 52 cross-sectional units. Although the data set was problematic to interpret, Hausman-Wu tests of endogeneity (values of -1.50 and 0.52 for agglomeration and SME respectively) confirmed the finding of Table 5 that the SME and agglomeration variables were in fact exogenous, whereas the firm creation variable was endogenous (Baten 2001, pp. 104-108). 
In this context, it is also interesting to introduce a lagged dependent variable. The creation rate of the previous period might proxy expected profits and a potential imitation impact. Moreover, we want to consider whether the explanatory variables become insignificant once this variable is added to the model. Regressions on the lagged creation rates indicate that history does matter indeed (Table 5, Column 3). We regressed the creation rates of 1897-1905 on the creation rates in 1874-96 (column 2). This creation rate of the most recent past is always highly significant and explains a high share of the variation in the dependent variable. $^{22}$

We also wanted to check how sensitive our models might react to including or excluding branch creations, and using the "city" level of regional aggregation. ${ }^{23}$ As we are able to distinguish independent firm creations from new branches, we excluded the latter in Table 5. As a result, the influence of the 'seed-bed effect' of regions with many small firms remains significant (Column 2 and 3). A 10 percent increase in the variable SME leads to $6.4 \%$ more firm creations. A tourist specialization clearly dampens creation activity. The agglomeration variable loses its statistical significance with this sample of firm creations in cities, but the coefficient remains economically meaningful. This result is relatively robust. However, the lagged dependent variable has an important influence among cities, too. An interpretation of this variable could be the "learning by example" (or imitation) effect described above, with high firm creation rates in period $\mathrm{t}-1$ directly impacting on creation in year $\mathrm{t}$, because potential firm creators could obtain knowledge by discussing the experience of those who set

22 In the previous regressions we kept the specification that the studies coordinated by the OECD used (see Reynolds et al. 1994) to make our estimates comparable, using OLS without transformations and including branch locations. But rates such as the firm creation rate are often characterised by skewed distributions. Checking the histogram and several skewness measures, we found the creation rate indeed to be skewed to the right. The same is true for our independent variables. We therefore employ a logarithmic transformation that has also the advantage of allowing the coefficients to be interpreted as elasticities. Kolmogorov-Smirnov normality tests indicated normally distributed residuals, so the logarithmic specification allows efficient estimation and hypothesis testing.

23 We also use the data on the 47 cities of Baden (with 2000+ inhabitants) to do further sensitivity checks. The differences between firm creation rates in those cities also turned out to be significantly influenced by the share of small and medium sized enterprises (Table 4, column 1). The significance of the coefficients indicates that the similar result for districts in the regressions above was probably not caused by casual interaction between the agglomeration and the SME factor. Only $8 \%$ of variation is explained, but after adding the tourism variable the $\mathrm{R}^{2}$ increases to a considerable $31 \%$, see www.uni-tuebingen.de/uni/wwl/baten_greb_table_cities.htm. Even if we have chosen cities to obtain more homogeneous geographical units, their degree of agglomeration is not completely the same, of course. There are some large cities such as Mannheim, Heidelberg, Freiburg and Karlsruhe on the one hand and small towns that mainly administered the surrounding region. We therefore test and find that a rural surrounding had a negative effect on the firm creation rate (Column 2-4). If the SME factor is considered alone, its determination coefficient rises considerably if only the larger cities (with 5000+ inhabitants) are included in the data set. 
up a business a few years ago. The success of those previous firm creators might have a motivating impact. We also included firm mortality here and found it insignificant. ${ }^{24}$ Finally, did the industry structure or age play a role? Audretsch and Fritsch (1999) found a strong variability of entry determinants across industries. We will not perform an analysis industry by industry here, but rather consider whether adding the shares of the most important industries to the model makes the other variables insignificant: one could imagine that some districts had creation intensive industries and others did not. However, including the shares of the most important industries did not change the results significantly (Table 5, column 4; see also Baten 2001, p. 140). In addition, we found the same non-significant results for the possible influence of age structure of the firms (results not shown, ibid.).

\section{Conclusion}

This paper reviewed a rapidly growing literature in industrial economics and regional economics that uses regional firm creation rates to answer the central question in entrepreneurship research: What makes entrepreneurs? Which factors encourage some people to set up their own business and create jobs, and what prevents potential entrepreneurs from doing so? Most contributions in economics that consider firm creations of the recent past suffer from severe data constraints. This is clearly a field in which economic history can provide important insights: Governmental supervision lists of firms before WWI were used in this contribution to reveal aspects of entrepreneurial behaviour that can only be investigated by historical economists.

In particular, Krugman's (1991) agglomeration theory and Audretsch and Fritsch's (1994) 'seed bed' theory of a beneficial SME environment have been tested and confirmed. In addition, a significant autoregressive term suggested that other factors are at work, perhaps a 'learning from example' effect: If your neighbour created a successful firm in the past, you are also more inclined to do so. The capital access hypothesis was only partly confirmed for the regional level; its proxy was significant only for the small firms. In contrast, nominal wages, taxes, and railway infrastructure did not influence firm creation rates significantly.

Coming back to the question we posed in the introduction: What does this mean for today's economic policy that attempts to reduce unemployment? It is unnecessary to mention that an economic policy decision should not be made relying on a historical data set alone. However, economic history can provide additional evidence and additional ideas for today's economic policy. A dynamic firm entry process is not the only determinant of job creation, but it is certainly one of the important preconditions. Looking from this perspective, we formulate five suggestions for today's economic policy:

(1) The frequently applied policy to keep large firms alive with subsidies (such as the Holtzmann AG in Germany a few years ago) seems most dubious - not only because

24 The coefficient of the mortality variable is positive (column 3 ). However, when the autoregressive effect of the past firm creation rate is controlled for, the significance is lost. 
subsidies always lead to distortions and disadvantage other firms, but also because of the detrimental impact on the firm creation process that was demonstrated in this article.

(2) We also found that capital access is critical only to smaller start-up firms. However, today's new-firm capital-support programs have a bias in favour of very ambitious startups that do not start very small, but need much capital. This is caused by the economics of bureaucracies that are better able to monitor a few large projects rather than many small ones. But with the increasing possibilities of computer technology, this limitation should be overcome and instead capital subsidies - if they are given at all - be provided to the very small start-up firms.

(3) The importance of agglomeration effects casts doubts on the policy to artificially subsidize rural regions. Although there are certainly benefits that might or might not outweigh the costs, the overall cost-benefir analysis should also take into account the detrimental impact on the firm creation process.

(4) The importance of minorities to create firms (that we found for the Jewish minority) suggests that immigration policies of the EU countries should be more focussed on entrepreunerial groups, as Canada does already for some time.

(5) The "learning by example", or imitation, process that we found to be strong poses challenges to school and university teachers, movie makers, the press and similar institutions to inform better about stories of firm creators. Especially if they are closely related to their respective audiences, such story-telling could encourage job-creation in new firms. This effect suggests that there are psychological forces driving the decision to set up one's own firm and to create jobs that are linked to regional or family identification and imitation patterns and that could be used to fight the economic problems of unemployment. 


\section{$\underline{\text { References }}$}

Abelshauser, W. (ed.) (2002). Die BASF. Eine Unternehmensgeschichte, München: C.H.Beck.

Audretsch, D./Michael F. (1994). "The Geography of Firm Births in Germany," Regional Studies 28-4 (1994), pp. 359-65.

Audretsch, D. and Fritsch, M. (1995). The Geographic and Industry Components of New Firm Startups in Germany. Discussion Paper FS IV 95-16. Wissenschaftszentrum Berlin fuer Sozialforschung.

Audretsch, D. and Fritsch, M. (1999). The Industry Component of Regional New Firm Formation Processes. Review of Industrial Organization, 15, 3, pp. 239-252.

Audretsch, D. and Jin J. (1994). A Reconcilation of the Unemployment - New Firm Startup Paradox, Small Business Economics 6-5 (1994), S. 381-385.

Audretsch, D. and Vivarelli M.(1994). "Determinants of New-Firm Startups in Italy," Empirica 23-1 (1996), pp. 91-105.

Baldwin, R. (1995), The dynamics ofindustrial competition, Cambridge: Cambridge University Press.

Baten, J. (1993). "Die wirtschaftliche Entwicklung der Stadt Lahr im 20. Jahrhundert," in: Geschichte der Stadt Lahr im 20. Jahrhundert edited by Stadt Lahr, Lahr: Kaufmann Verlag, pp. 45-66.

Baten, J. (2001). Gruendung, Produktivitaet und Erfolg von kleinen und grossen Unternehmen in Deutschland, 1880-1913. Unpublished, book-length manuscript Muenchen/Tuebingen. Available under www.tuebingen.de/uni/wwl/habil.doc

Bender, G. (1978). Die Uhrenmacher des hohen Schwarzwaldes und ihre Werke, vol. 2, Villingen- Schwenningen: Verlag Müller.

Boegenhold, D./Staber, U. (1990): Selbständigkeit als ein Reflex auf Arbeitslosigkeit? Makrosoziologische Befunde einer international-komparativen Studie. Kölner Zeitschrift für Soziologie und Sozialpsychologie, 2, S. 265-279.

Boelcke, W. A. (1987). Wirtschaftsgeschichte Baden-Württembergs von den Römern bis heute, Stuttgart: Konrad Theiss Verlag.

Borchardt, K. (1976), Wirtschaftliches Wachstum und Wechsellagen, in: Aubin, H. and Zorn W. (eds.), Handbuch der Wirtschafts- und Sozialgeschichte, vol. 2. Stuttgart: Klett, pp. 198-275.

Borscheid, P. (1976). Naturwissenschaft, Staat und Industrie in Baden, 1848-1914, Stuttgart: Klett.

Central-Blatt (1897). Central-Blatt für das Deutsche Reich, Anhang zu Nr. 52 1897:

Ortsübliche Tagelöhne gewöhnlicher Tagearbeiter, ... zusammengestellt im Kaiserlichen Statistischen Amte, pp. 421-783.

Davidsson, P., Lindmark, L. and Olofsson, C. (1994). New Firm Formation and Regional Development in Sweden. Regional Studies 28-4 (1994), pp. 395-410.

Fischer, W. (1989). Staat und Wirtschaft im 19. Jahrhundert, in Ott Borst (ed.), Wege in die Welt. Die Industrie im deutschen Südwesten seit Ausgang des 18. Jahrhunderts, Stuttgart: Deutsche Verlagsanstalt, pp. 89-106. 
Fischoff, E. (1968). Die protestantische Ethik und der Geist des Kapitalismus. Die Geschichte einer Kontroverse (originally in Social Research XI (1944), S. 53-77, cited here from Max Weber: Die protestantische Ethik II: Kritiken and Antikritiken, ed. by Johannes Winckelmann, München/Hamburg: Siebenstern TB-Verlag, pp. 346-379.

Frank, H. (1994). Regionale Entwicklungsdisparitäten im deutschen Industrialisierungsprozess 1949-1939: eine empirisch-analytische Untersuchung. Münster/Hamburg: LIT Verlag.

Fritsch, M. (1994). "Regionale Unterschiede des Gründungsgeschehens in Westdeutschland 1986-1989: Eine empirische Analyse," in Schmude, Jürgen (ed.): Neue Unternehmen. Interdisziplinäre Beiträge zur Gründungsforschung, Heidelberg, pp. 24-35.

Garofoli, G. (1994). "New Firm Formation and Regional Development: The Italian Case" in Regional Studies 28-4, pp. 381-393.

Gerlach, K. and Schmidt, E. (1990). Firm Size and Wages. Labour 4-2 (Autumn 1990), pp. 27-49.

Gerlach, K. and Wagner (1994). Regional Differences in Small Firm Entry in Manufacturing Industries: Lower Saxony, 1979-1991. Entrepreneurship \& Regional Development 6 (1994), pp. 63-80.

Geroski, P. (1991), Market dynamics and entry, Oxford: Blackwell Pub1ishers.

Hallerberg, M. (1995). Tax Competition, Political Institutions, and Democratization: The Development of State Tax Systems in Wilhelmine Germany. Diss. UCLA. UMI 9601352.

Handbuch (1992). Handbuch der Baden-Württembergischen Geschichte, vol. III. Stuttgart: Klett Cotta.

Herrigel, G. (1996). Industrial Constructions: The Sources of German Industrial Power. Cambridge: Cambridge University Press.

Krugman, P. (1991). Increasing Returns and Economic Geography. Journal of Political Economy 99-3 (Juni 1991), pp. 483-499

Krugman, P. (1994). Geography and trade. Leuven: Leuven Univ. Press et al.

Krugman, Pa. (1998). Space: The Final Frontier. Journal of Economic Perspectives 12-2 (Spring 1998), pp. 161-174.

O'Rourke, K. and Williamson, J. (1999). Globalization and History. Cambridge: Cambridge University Press.

Orr, D. (1974). The Determinants of Entry: A Study of the Canadian Manufacturing Industries. Review of Economics and Statistics, 56, 1, pp 58-66.

Pierenkemper, T. (1987). The Standard of Living and Employment in Germany, 1850-1980: An Overview. Journal of European Economic History, 16, pp. 51-73.

Puffert, D. (2002). Path Dependence in Spatial Networks: The Standardization of Railway Gauge Standardization. Explorations in Economic History 39, pp. 282-314.

Reynolds, P.D./Storey, D.J./Westhead, P (1994). Cross National Comparisons of the Variation in New Firm Formation Rates. Regional Studies 27 (1994), pp. 443-456.

Sabel, C.F. and Zeitlin, J. (eds.), World of Possibilities. Flexibility and Mass Production in Western Industrialization. Cambridge: Cambridge Univ. Press.

Schumpeter, J. (1926). Theorie der wirtschaftlichen Entwicklung. Muenchen/Leipzig, $2^{\text {nd }}$ edition: Duncker\&Humblot. 
Solar, P. (1997). "The Birth and Death of the European Flax, Hemp and Jute Spinning Firms: The Irish and Belgian Cases" Proceedings of the Third World Congress of Cliometrics, Munich July 10-13, 1997, pp. 103-112.

Statistisches Jahrbuch für das Großherzogthum Baden (various issues). Karlsruhe.

Storey, D.J. and Johnson, S.G. (1987): Job Creation in Small and Medium Sized Enterprises ( $=$ Commission of the European Communities, Programme of Research and Actions on the Development of the Labor Market). Brussels: EC documents.

Storey, D.J. et al. (1987), The Performance of Small Firms. Beckenham: Croom Helm.

Taylor, A. (1996). „International Capital Mobility in History: The Saving-Investment Relationship“ NBER-Working Paper 5743, 1996.

Tilly, R.H. (1997), German Banking 1850-1914: Development Assistance for the Strong, in: John Komlos/Scott Eddie (ed.), Selected Cliometric Studies on German Economic History. Stuttgart: Steiner Verlag, pp. 172-195.

Verzeichnis $(1895,1906)$ der einer besonderen Aufsicht unterliegenden Fabriken und diesen gleichgestellten Gewerbebetrieben. Unpublished manuscripts, State library Karlsruhe and University Library Freiburg.

Voigtel, M. (1903). Die direkten Staats- und Gemeindesteuern im Grossherzogthum Baden, eine Darstellung ihrer Entwickelung und Ergebnisse von 1886-1901. Ph.D. thesis Heidelberg. Jena: Gustav Fischer.

Vries, J. de (1994). "The Industrial Revolution and the Industrious Revolution. Journal of Economic History 54-2 (June 1994), pp. 249-70.

Weber, M. (1924). Gesammelte Aufsätze zur Sozial- und Wirtschaftsgeschichte. Tübingen: J.C.B. Mohr 1924.

Whittington, R. (1986). "Regional Bias in New Firm Formation," in M. Scott et al. (eds.): Small Firms Growth and Development. Grower: Aldershot.

Williamson, J.G. (1996). Globalization, Convergence and History. Journal of Economic History 56-2 (1996), S. 277-306. 
Table 1: Nearest percentiles of Baden's four Bezirke (counties), relative to Germany's 78 Bezirke

\begin{tabular}{lcccc}
\hline \hline County & $\begin{array}{c}\text { Rural wage } \\
\text { (nominal) }\end{array}$ & $\begin{array}{c}\text { Urban wage } \\
\text { (nominal) }\end{array}$ & $\begin{array}{c}\text { Rural wage } \\
\text { (real) }\end{array}$ & Patents p.c. \\
\hline Freiburg & 81 & 97 & 65 & 62 \\
Karlsruhe & 75 & 86 & 56 & 74 \\
Mannheim & 73 & 86 & 49 & 83 \\
Konstanz & 69 & 70 & 47 & 32 \\
\hline \hline
\end{tabular}

All data are first expressed as ranks for the 76 (urban nom. wage), 77 (rural nom\&real wage) und 78 (patents) (Regierungs-)bezirke for which we had data, then they are expressed as percentiles (rounded).

"Rural wage" and "Urban wage" are nominal wages. Patenting activity refers to 1897-1905. Source: Hohenheim/Tübingen database on influential patents, thanks to Jochen Streb and Shuxi Yin for letting me use this information. 
Table 2: Results of the regression for today: determinants of the firm creation rates in industry in the late $1980 \mathrm{~s}$

\section{Country/Regression}

\section{Germany}

Ireland

Italy

Sweden

UK

USA

Demand

SPop./Immigration

$\delta$ GDP

0

0

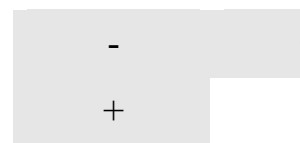

$\begin{array}{ll}+ & + \\ 0 & 0\end{array}$

$+\quad+$

0

Agglomeration

\%Age 25-44

Pop. density

\%Manager

\%University

\begin{tabular}{ccc}
0 & & 0 \\
+ & - & + \\
\hline 0 & + & 0 \\
& - & 0
\end{tabular}

0

0

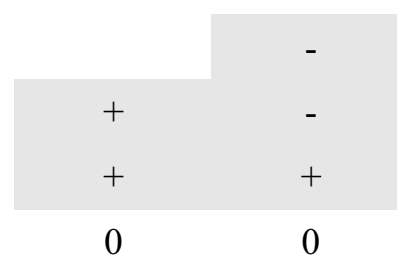

Unemployment

Level

Change

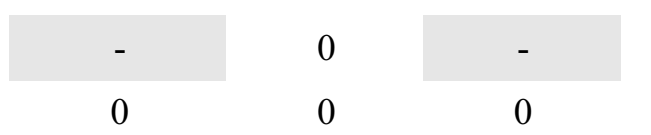

$\begin{array}{ll}0 & 0 \\ 0 & 0\end{array}$

0

Personal property

Income of households

$\%$ Owner-occupied houses

0

0

0

House prices

0

0

0

0

0

0

$+$

\section{SME/Specialization}

\%employed in SME

Specialization

\begin{tabular}{|c|c|c|c|c|c|}
\hline+ & + & + & + & + & + \\
\hline 0 & 0 & + & & & 0 \\
\hline
\end{tabular}

Policy

\%Socialist. Voters

Communal expenditures

0

0

Aid programs

$\mathrm{N}$

74

$+\quad 0$

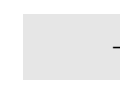

$+$

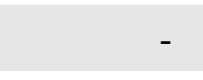

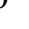

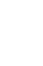

0

0

Adj. $\mathrm{R}^{2}$

0.51

27

84

0

0

80

64

392

Notes: + positively significant; - negatively significant; 0 insignificant. Shaded are explanatory variables that are significant at the 0.10-level. Empty space: variables not included in the regression. All regression are OLS without transformation. Source: Reynolds/Storey/Westhead (1994). 
Table 3: Five Regressions of firm creation rates around 1900 (districts of Baden) and in the late 1980's. (Germany, regional planning units)

\begin{tabular}{|c|c|c|c|c|c|}
\hline Col/Sample & (1) & (2) & \multicolumn{3}{|c|}{$(3-5)$} \\
\hline a) Firm sizes & 1-50 w. & $\begin{array}{l}\text { All firm } \\
\text { sizes }\end{array}$ & \multicolumn{3}{|c|}{ Larger firms (10+ workers 1906) } \\
\hline b) Period & $1986-89$ & 1896 & $1897-1905$ & $1897-1905$ & $1897-1905$ \\
\hline c) Region & Germany & Baden & Baden & Baden & Baden \\
\hline \multicolumn{6}{|l|}{ Explanat. Variables: } \\
\hline SME & $\begin{array}{c}0.69 \\
(8.47)\end{array}$ & $\begin{array}{c}0.21 \\
(0.00)\end{array}$ & $\begin{array}{c}0.32 \\
(0.02)\end{array}$ & $\begin{array}{c}0.33 \\
(0.02)\end{array}$ & $\begin{array}{c}0.90 \\
(0.01)\end{array}$ \\
\hline Industrial agglomeration & & $\begin{array}{c}0.22 \\
(0.09)\end{array}$ & $\begin{array}{c}0.51 \\
(0.02)\end{array}$ & $\begin{array}{c}0.44 \\
(0.05)\end{array}$ & $\begin{array}{l}1.70 \\
(0.00)\end{array}$ \\
\hline Tourism & & $\begin{array}{l}-0.38 \\
(0.00)\end{array}$ & $\begin{array}{l}-0.45 \\
(0.00)\end{array}$ & $\begin{array}{l}-0.44 \\
(0.05)\end{array}$ & $\begin{array}{l}-1.19 \\
(0.00)\end{array}$ \\
\hline Capital & $\begin{array}{c}0 \\
(0.00)\end{array}$ & $\begin{array}{c}0.73 \\
(0.00)\end{array}$ & $\begin{array}{c}0.06 \\
(0.75)\end{array}$ & $\begin{array}{l}-0.09 \\
(0.67)\end{array}$ & \\
\hline Master in SME & $\begin{array}{c}0.39 \\
(5.16)\end{array}$ & & & & \\
\hline Railways & & & & $\begin{array}{c}0.11 \\
(0.43)\end{array}$ & \\
\hline Nominal wages & & & & $\begin{array}{c}0.06 \\
(0.71)\end{array}$ & \\
\hline High taxation & & & & $\begin{array}{l}0.14 \\
0.28\end{array}$ & \\
\hline Firm mortality & & & & & $\begin{array}{l}-0.33 \\
(0.60)\end{array}$ \\
\hline \multicolumn{6}{|l|}{ Constant } \\
\hline $\begin{array}{l}\text { Kreis regional effects } \\
\text { controlled }\end{array}$ & NO & NO & NO & NO & YES \\
\hline Adj. R2 & 0.65 & 0.82 & 0.36 & 0.37 & 0.44 \\
\hline $\mathrm{N}$ & 84 & 52 & 52 & 52 & 47 \\
\hline
\end{tabular}

The constant is not given in the table because of using BETA coefficients, except in column 5, in which elasticities are reported (all variables in logs). No WLS performed, except col. 2 and 5 (with population 1895). Col. 1: t-values in parentheses. Col 2-5: p-values in parentheses. Shading indicates significance at the 0.10 -level.

Dependent variable: Col. 1: Germany - new firms 1986-89, which set up with 1-50 employees and survived at least 2 years (per employed for 84 western German regions); source: Fritsch, 1994. Col. 2 : Baden - All new firms 1896 per population; source: Statistical Yearbook Baden 29 (1897/98), p. 160163. Col. 3-5: Firm creations 1897-1905 (per number of employed in 1895), which have had 10 or more employees in 1906; source: Verzeichnis $(1895,1906)$.

SME: Baden 1897-1906: Share of employees in firms with less than 100 employed, for Germany 1986-89 the threshold value is 200 employees. Access to capital: Baden: Kapitalrentensteuerkapital in 1000 Mark per head, for 1896. (Source: Statistical Yearbook Baden 29, 1898), pp. 462-463: Germany: "Share of owner-occupied housing as an indicator of loan capital availability", compare Fritsch (1994), p. 30f. Tourism: Share of persons employed in "Beherbergung und Erquickung" (housing and refreshment) in 1895 to the total number of employees in industry (Source: Statistical 
Yearbook Baden 29 (1898), p. 158f. Railway equals 1, if the district included at least one station of the main line, see "Historischer Atlas von Baden-Württemberg", Blatt X.4. Nominal wages in Mark refer to both male and female unskilled workers in for 1898. Regionally differentiated wages for other occupations are not available. Firm Mortality: Share of firms with 10+ workers in 1895 that did not survive until 1906. 
Table 4: Does mentality influence firm cration? Regressions of firm creation rates on religious variables 1897-1905.

\begin{tabular}{|c|c|c|c|}
\hline & $\begin{array}{c}\text { with protestant } \\
\text { variable }\end{array}$ & $\begin{array}{c}\text { with jewish } \\
\text { variable }\end{array}$ & with all variables \\
\hline Protestant share & $\begin{array}{c}0.36 \\
(0.01)\end{array}$ & & $\begin{array}{l}-0.11 \\
(0.41)\end{array}$ \\
\hline Jewish share & - & $\begin{array}{c}0.29 \\
(0.04)\end{array}$ & $\begin{array}{c}0.24 \\
(0.06)\end{array}$ \\
\hline SME & - & - & $\begin{array}{c}0.42 \\
(0.00)\end{array}$ \\
\hline Industrial agglomeration & - & - & $\begin{array}{c}0.40 \\
(0.00)\end{array}$ \\
\hline Tourism & - & - & $\begin{array}{l}-0.35 \\
(0.02)\end{array}$ \\
\hline High taxation & - & - & $\begin{array}{l}-1.09 \\
(0.77)\end{array}$ \\
\hline Adj. R2 & 0.11 & 0.07 & 0.48 \\
\hline $\mathrm{N}$ & 52 & 52 & 52 \\
\hline
\end{tabular}

All regressions are WLS, weighted with the number of inhabitants 1895. All coefficients are BETAcoefficients (therefore no constant given). P-values in parenthesis. Shading indicates coefficients significant at a 0.05 -level. Sources: See Table 3.

Protestant confession: share of protestants of the entire population (census 1895). Jewish religion: share of Jewish of the entire population (census 1895). 
Estimation and

specification

Regional units

With or without

Districts

without

Cities

Districts

lagged creation

rate

Constant

$-7.63$

$(0.09)$

creation rate,

previous period

SME

0.85

(0.18)

1.44

(0.06)

$-1.34$

Tourism

(0.00)

Firm mortality without

with

1.27

$-3.70$

$(0.58)$

$(0.21)$

$(0.10)$

0.37

$(0.14)$

$-1.31$

0.60

$(0.17)$

$(0.00)$

0.37

0.67

(0.02)

0.51

0.73

without
$(0.02)$

OLS, with industry shares 


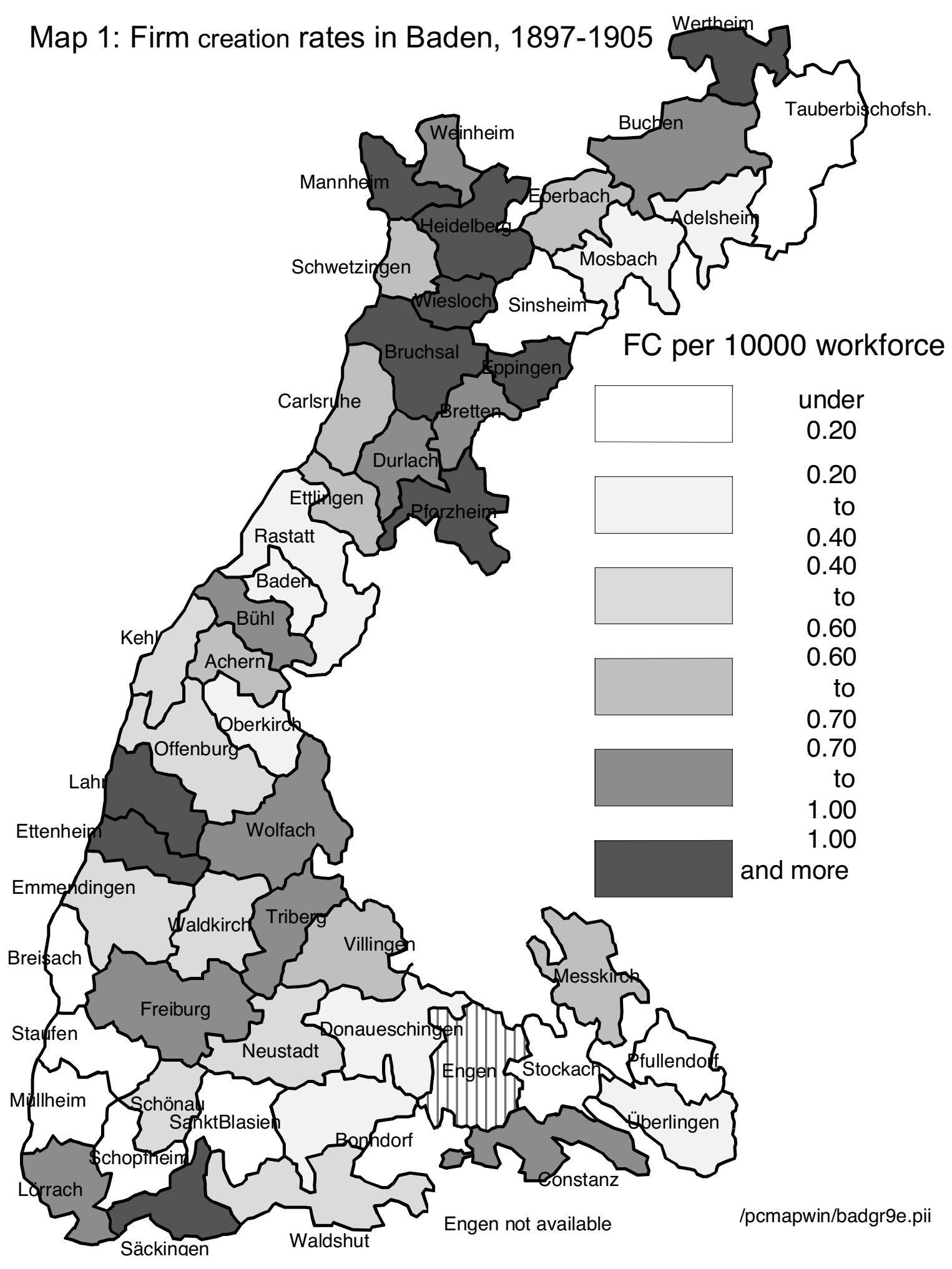




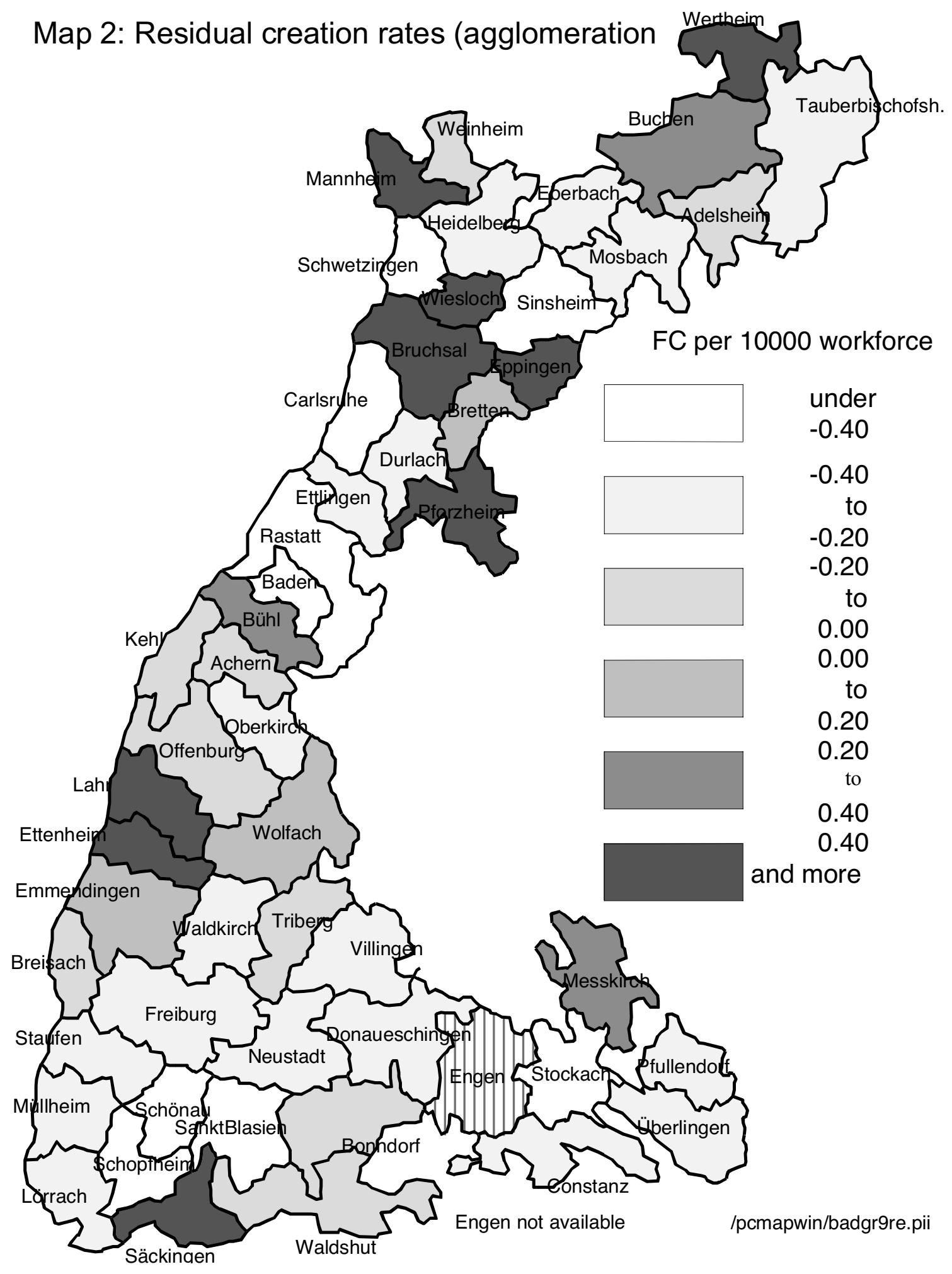





\section{IAW-Diskussionspapiere}

Bisher erschienen:

Nr. 1

Das Einstiegsgeld - eine zielgruppenorientierte negative Einkommensteuer:

Konzeption, Umsetzung und eine erste Zwischenbilanz nach 15 Monaten

in Baden-Württemberg

Sabine Dann / Andrea Kirchmann / Alexander Spermann / Jürgen Volkert

Nr. 3

Gut betreut in den Arbeitsmarkt? Eine mikroökonomische Evaluation der

Mannheimer Arbeitsvermittlungsagentur

Jürgen Jerger / Christian Pohnke / Alexander Spermann

Nr. 4

Das IAW-Einkommenspanel und das Mikrosimulationsmodell SIMST

Peter Gottfried / Hannes Schellhorn

Nr. 5

A Microeconometric Characterisation of Household Consumption Using

Quantile Regression

Niels Schulze / Gerd Ronning

Nr. 6

Determinanten des Überlebens von Neugründungen in der baden-württembergischen Industrie - eine empirische Survivalanalyse mit amtlichen Betriebsdaten

Harald Strotmann

Nr. 7

Die Baulandausweisungsumlage als ökonomisches Steuerungsinstrument einer nachhaltigkeitsorientierten Flächenpolitik

Raimund Krumm

Nr. 8

Making Work Pay: U.S. American Models for a German Context?

Laura Chadwick, Jürgen Volkert 
Nr. 9

Erste Ergebnisse von vergleichenden Untersuchungen mit anonymisierten und nicht anonymisierten Einzeldaten am Beispiel der Kostenstrukturerhebung und der Umsatzsteuerstatistik

Martin Rosemann

Nr. 10

Randomized Response and the Binary Probit Model

Gerd Ronning

Nr. 11

Creating Firms for a New Century: Determinants of Firm Creation around 1900 Joerg Baten 